\title{
MICROBIAL ACTIVITY IN A SOIL WITH COVER CROPS IN SUCCESSION WITH MAIZE IN A NO-TILLAGE SYSTEM
}

\author{
Cátia Aparecida Simon ${ }^{1}$, Meire Silvestrini Cordeiro ${ }^{2}$, Sebastião Ferreira de Lima ${ }^{2}$, Marivaine da Silva \\ Brasil $^{3}$, Carlos Henrique De David ${ }^{2} \&$ Vinícius Andrade $\mathrm{Secco}^{2}$
}

\footnotetext{
${ }^{1}$ Escola Superior de Agricultura Luiz de Queiroz, ESALQ/USP. Piracicaba, Brasil. E-mail: catiasimonsimon@gmail.com

${ }^{2}$ Universidade Federal de Mato Grosso do Sul, Campus de Chapadão do Sul, Chapadão do Sul. E-mail: meire.cordeiro@ufms.br, sebastiao.lima@ufms.br, carlosbed_22@hotmail.com

${ }^{3}$ Universidade Federal de Mato Grosso do Sul, Campus do Pantanal, Corumbá. E-mail: marivaine.brasil@ufms.br
}

\section{ABSTRACT}

Microbial activity can be used to monitor soil quality, since it provides evidence of soil biological behavior according to the management practices used. The objective of this work was to evaluate the effect of different cover crops in succession to maize on the biochemical indicators of a Dystrophic Red Latosol in the Cerrado region of the state of Mato Grosso do Sul. Eight different cover crops were evaluated: sorghum, millet, stylosanthes, Urochloa ruziziensis, forage turnip, Urochloa brizantha $c v$. Marandu, crambe, and fallow, with three replications. Acid phosphatase, arylsulfatase, and $\beta$-glucosidase varied, respectively, from 755 to $1111 ; 74$ to 131 ; and 167 to $299 \mu \mathrm{g}$ p-nitrophenol $\mathrm{g} \mathrm{soil}^{-1} \mathrm{~h}^{-1}$. Soil basal respiration ranged from 126 to $171 \mathrm{mg} \mathrm{C}-\mathrm{CO}_{2} 100 \mathrm{~g}^{-1}$ dry soil. The different soil cover crops used in succession to maize influenced soil quality biochemical indicators. U. ruziziensis cover crop provided the best results for the attributes evaluated in the soil and climate conditions of the Cerrado region of the state of Mato Grosso do Sul.

Keywords: Microbiological indicators, crop rotation, soil quality

\section{ATIVIDADE MICROBIANA EM SOLO COM ROTAÇÃO DE PLANTAS DE COBERTURAS NO SISTEMA DE PLANTIO DIRETO}

\section{RESUMO}

A atividade microbiana pode ser utilizada para monitorar a qualidade do solo, fornecendo evidências do seu comportamento biológico de acordo com o manejo. Objetivou-se com este trabalho avaliar o efeito de diferentes plantas de cobertura em sucessão a cultura do milho, nos indicadores bioquímicos de um Latossolo Vermelho distrófico no Cerrado sul-mato-grossense. Foram avaliadas oito diferentes coberturas vegetais: sorgo, milheto, estilosantes, Urochloa ruziziensis, nabo forrageiro, Urochloa brizantha cv. Marandu, 
crambe e pousio, com três repetições. A fosfatase ácida, arilsufatase e $\beta$-glucosidase variaram respectivamente de 755 a 1111; 74 a 131 e 167 a $299 \mu \mathrm{g}$ p-nitrofenol $\mathrm{g} \mathrm{solo}^{-1} \mathrm{~h}^{-1}$. A respiração basal do solo variou de 126 a $171 \mathrm{mg} \mathrm{C}-\mathrm{CO}_{2} 100 \mathrm{~g}^{-1}$ solo seco. As diferentes plantas de cobertura do solo utilizadas em sucessão a cultura do milho influenciaram os indicadores bioquímicos de qualidade do solo. A cobertura vegetal $U$. ruziziensis proporcionou os melhores resultados nos atributos avaliados nas condições edafoclimáticas do Cerrado sul-mato-grossense.

Palavras-chave: Indicadores microbiológicos, sucessão de culturas, qualidade do solo

\section{INTRODUCTION}

The intensive use of the soil for agricultural production requires adequate management of the crops, aiming at sufficient straw production for the maintenance of no-tillage system in the Cerrado biome (GALBIATTI et al., 2011).

The use of crop succession, by interspersing crops with high potential for straw production and low decomposition rate with crops that promote nutrient cycling and biological nitrogen fixation, are recurrent practices in the no-tillage system (LEAL et al. 2005).

Several plant species have been used as cover crop to improve the environment for subsequent crops, especially millet, which is one of the species responsible for the expansion of the no-tillage system in the central region of Brazil, mainly due to the large amount of biomass produced and to the high resistance to drought and good nutrient cycling (PACHECO et al., 2011). Other species have been studied, such as sorghum, forage turnip, crotalaria, and crambe (CARVALHO et al., 2015, HEINZ et al., 2011). These species have been introduced by crop rotation or succession, in which the management of cultural remains interferes with the period necessary for mineralization, and may alter the soil microbial community (REIS et al., 2011). Alves et al. (2011) stated that the introduction of crops into agricultural systems establishes a new soil balance condition, and that microbial community monitoring can serve as a criterion for detecting changes in soil quality.

Several biological indicators can be used for soil monitoring, and the enzymatic activity stands out as a sensitive indicator of soil quality, providing important information on the changes in key soil functions (ARAÚJO \& MONTEIRO, 2007).

The evaluation of catalytic enzymes, such as $\beta$-glucosidase, phosphatase and arylsulfatase, which are involved in the biogeochemical transformations of carbon, phosphorus and sulfur, respectively (LAMBAIS \& CARMO, 2008; LAGOMARSINO et al., 2009), as well as the analysis of soil basal 
respiration, which quantifies the $\mathrm{CO}_{2}$ released by the soil and indicates the metabolic activity of its microbial population (ISLAM \& WEIL, 2000), allow the estimation of the sustainability of soil management in a given region. Thus, the evaluation and knowledge of the processes in which the microbial community is involved are important steps in the choice of the most appropriate soil management system, mainly aiming at soil conservation.

The objective of this work was to evaluate the effect of different cover crops in succession to maize on biochemical indicators of a Dystrophic Red Latosol in the Cerrado region of the state of Mato Grosso do Sul, in Brazil.

\section{MATERIAL AND METHODS}

The experiment was carried out in the 2015/2016 harvest, in the experimental area of the Federal University of Mato Grosso do Sul, Campus of Chapadão do Sul, in the municipality of Chapadão do Sul, in the state of Mato Grosso do Sul, Brazil. The climate is tropical humid (Cwa), according to the Köppen classification, with annual temperature between 13 and $29{ }^{\circ} \mathrm{C}$, annual rainfall of 1,850 mm, and with rainy summer and dry winter (CUNHA et al., 2013). The soil is classified as Dystrophic Red Latosol, with the following chemical and granulometric characteristics at the $0.0-0.20 \mathrm{~m}$ depth layer: $\mathrm{pH}\left(\mathrm{CaCl}_{2}\right)$ 4.6; O.M.: 23.1 and O.C.: $13.4 \mathrm{~g} \mathrm{dm}^{-3}$; P: $10.9 \mathrm{mg} \mathrm{dm}^{-3}$; K, Ca, Mg, Al, Ca+Mg, and H+Al of 0.13; 1.40; $0.40 ; 0.18 ; 1.80 ;$ and $5.6 \mathrm{cmol}_{\mathrm{c}} \mathrm{dm}^{-3}$, respectively, and V\% 36.6, clay: 44\%, sand: $49 \%$, and silt: $7 \%$.

The no-tillage system was installed in the experimental area in 2013, using cover crops in succession to maize. Treatments were formed by eight different cover crops in the winter crop: sorghum (Sorghum bicolor), millet [Pennisetum glaucum (L.) R. Br.], stylosanthes (Stylosanthes spp / CV. BRS), Urochloa ruziziensis, forage turnip (Raphanus sativus L.), Urochloa brizantha cv. Marandu, crambe (Crambe abyssinica Hochst), and fallow. Cover crops were sown in March and mowed in September, 2015, and maize was sown in November, 2015, in the summer crop under the brush.

The experiment consisted of randomized blocks design, with eight treatments and three replications. The experimental plot in the summer crop with maize was made up of five $5 \mathrm{~m}$ row, spaced $0.50 \mathrm{~m}$ between rows. The three central rows of the plot were considered as useful area.

Samples were collected in January 2016, at the full flowering stage of the maize crop, at 0.0 to $0.20 \mathrm{~m}$ depth, with the aid of a Dutch auger. Five samples were collected at different points to form a composite sample of each plot, and for each sample, five points perpendicular to the planting row were 
removed. Samples were sieved in the field, using a $4 \mathrm{~mm}$ mesh sieve, and stored in a cold chamber at 4 ${ }^{\circ} \mathrm{C}$, until its use.

The enzymes acid phosphatase, arylsulfatase and $\beta$-glucosidase were evaluated according to the methods described by Tabatabai (1994). These methods consist of incubating the soil samples in the presence of specific substrates, para-nitrophenyl phosphate, para-nitrophenyl sulfate and paranitrophenyl- $\beta$-D-glucopyranoside, both at $0.5 \mathrm{~mL} \mathrm{~L}^{-1}$, at a temperature of $37^{\circ} \mathrm{C}$, for $1 \mathrm{~h}$. Due to this short incubation period, toluene was not included in the procedures. After filtration, the p-nitrophenol (PNF) concentration present in the samples was determined based on the standard curve of each enzyme, with spectrophotometer readings at $410 \mathrm{~nm}$ for phosphatase and arylsulfatase and at $420 \mathrm{~nm}$ for $\beta$-glucosidase, expressed in $\mu \mathrm{g}$ PNF soil ${ }^{-1} \mathrm{~h}^{-1}$. Analysis was performed in triplicate for each of the field replications.

Soil basal respiration was determined by incubating wet soil samples (100 g) with $20 \mathrm{~mL}$ of water and $20 \mathrm{~mL}$ of $0.5 \mathrm{M} \mathrm{NaOH}$ in $2000 \mathrm{~mL}$ bottles, which were hermetically sealed and incubated for 7 days at $30{ }^{\circ} \mathrm{C}$ in the darkness. The released $\mathrm{CO}_{2}$ was determined by titrating the remaining $\mathrm{NaOH}$ solution from the bottles with $1 \mathrm{M} \mathrm{HCl}$, using phenolphthalein as indicator.

Analysis of variance and means comparison for the results of all biochemical evaluations were performed using the Scott-Knott test at 5\% probability in the SISVAR software (FERREIRA, 2011).

\section{RESULTS AND DISCUSSION}

Biochemical indicators of soil quality evaluated by the enzymes (acid phosphatase, arylsulfatase and $\beta$-glucosidase) and by soil basal respiration were influenced by the different treatments of this study ( $\mathrm{p}<0.05)$, as described in Table 1 and Figure 1.

Soil with $U$. ruziziensis cover, in the winter crop prior to maize cultivation, showed the highest activity of the acid phosphatase enzyme ( $<<0.05)$, when compared with the other treatments. Cover crops promoted soil residual effects, affecting phosphatase activity in the following sequence: U. ruziziensis > sorghum $>U$. brizantha $c v$. Marand $u=$ millet $=$ fallow $>$ crambe $=$ stylosanthes $=$ forage turnip $($ Table 1). Greater activity of this enzyme was observed in soil under grass cover crops. According to Carneiro et al. (2008), the highest concentration of acid phosphatase observed in soil with the presence of these species may be associated with their fasciculated root system, which is concentrated at the first $10 \mathrm{~cm}$ depth, resulting in greater input of carbon into the soil, via rhizosphere and necromass, acting in the activation of the soil microbiota. 
Table 1. Enzymatic activity in soil cultivated with maize with different cover crops in the winter crop. Chapadão do Sul, January $/ 2016$.

\begin{tabular}{lccc}
\multicolumn{1}{c}{ Cover crops } & $\begin{array}{c}\text { Acid } \\
\text { Phosphatase }\end{array}$ & Arilsufatase & $\beta$-glucosidase \\
& & $\left(\mu \mathrm{g} \mathrm{PNF} \mathrm{g} \mathrm{soil}{ }^{-1} \mathrm{~h}^{-1}\right)$ & \\
\hline Sorghum & $972.30 \mathrm{~b}$ & $101.94 \mathrm{a}$ & $168.60 \mathrm{c}$ \\
Millet & $838.54 \mathrm{c}$ & $90.61 \mathrm{~b}$ & $299.50 \mathrm{a}$ \\
Stylosanthes & $727.79 \mathrm{~d}$ & $91.22 \mathrm{~b}$ & $162.78 \mathrm{c}$ \\
U. ruziziensis & $1111.63 \mathrm{a}$ & $117.46 \mathrm{a}$ & $238.83 \mathrm{~b}$ \\
Forage turnip & $671.21 \mathrm{~d}$ & $74.45 \mathrm{~b}$ & $167.82 \mathrm{c}$ \\
U. brizantha cv. Marandu & $877.98 \mathrm{c}$ & $116.95 \mathrm{a}$ & $249.91 \mathrm{~b}$ \\
Crambe & $755.97 \mathrm{~d}$ & $97.66 \mathrm{~b}$ & $237.30 \mathrm{~b}$ \\
Fallow & $833.28 \mathrm{c}$ & $131.03 \mathrm{a}$ & $212.85 \mathrm{~b}$ \\
\hline
\end{tabular}

*Values followed by the same letter in the column did not differ from each other $(\mathrm{p}<0.05)$ by the Scott-Knott test at $5 \%$ probability

Soil cultivated with $U$. brizantha cv. Marandu cover crop presented lower value of acid phosphatase activity than that found in soil cultivated with $U$. ruziziensis cover crop, although they belong to the same genus. Machado \& Assis (2010), in a study on the production of straw in the soil verified that $U$. brizantha cv. Marandu produced less straw when compared with $U$. ruziziensis, being $3,344 \mathrm{~kg}$ ha-1 and 4,576 kg ha-1, respectively. Thus, it can be inferred that the amount of residues deposited in the soil altered the dynamics of the microbial community, increasing enzymatic activity.

Nahas (2002), in a study with different cultivation systems with $U$. ruziziensis, legumes and fallow, reported greater presence of microorganisms with acid phosphatase activity in soil under grass cover, which possibly occurred in this study. Rosolem et al. (2014), when evaluating phosphorus dynamics in relation to $U$. ruziziensis and phosphate fertilizers, verified that acid phosphatase decreased with the application of phosphorus, but increased in the presence of this species in relation to the treatment without plants. According to these authors, the adoption of $U$. ruzizienses in crop rotation in no-tillage systems can increase the efficiency in the use of phosphorus over time, including the absorption of less labile fractions.

When comparing the acid phosphatase activity in the soil with $U$. ruziziensis cover crop in relation to the fallow soil, a 25\% increase in enzyme activity was observed. Cultivation with sorghum cover crop also provided the soil with higher enzyme activity in relation to fallow, and the cover crops U. brizantha and millet had similar values, even when compared with fallow (Table 1). These comparisons are important, since fallow is widely used in agricultural properties in Cerrado soils. In this treatment, the following species were found: Conyza bonariensis, Tridax procumbens, Chromolaena maximilianii, Ageratum conyzoides, Commelina benghalensi, Ipomoea grandifolia, Cyperus rotundus, and Urochloa 


\section{MICROBIAL ACTIVITY IN A SOIL WITH COVER CROPS IN SUCCESSION WITH MAIZE IN A NO- TILLAGE SYSTEM}

decumbens. This diversity of species and residues may have influenced the results of microbial activity of this study. However, the use of fallow as management system is not recommended in agricultural soils for several reasons, such as: the uneven promotion of the cover crop in the soil; the increase of the bank of weeds seeds, resulting in the competition with the crop in the next harvest; and the high probability of hosting agricultural pests, which increases production costs (CHRISTOFFOLETI \& PASSINI, 1999).

The enzymes acid phosphatase, arylsulfatase and $\beta$-glucosidase, in general, showed lower values of soil activity under forage turnip and crambe cover crops (Table 1). This may be related to the fact that these species are non-myotrophic plants, which influences the development and growth of mycorrhizal fungi of the subsequent crop (OERLEMANS et al., 2006), interfering indirectly with the microbial population, and consequently with the enzymatic activity of the soil.

The values for the arylsulfatase enzyme activity in the soil presented the following decreasing sequence, according to the cover crop: fallow $=U$. ruziziensis $=U$. brizantha $=$ sorghum $>$ crambe $=$ stylosanthes $=$ forage turnip $($ Table 01$)$.

Greater arylsulfatase enzyme activity was observed in the fallow soil and under grass cover crops, corroborating with Lisboa et al. (2012), who worked with crop rotations and fallow in different soil preparation systems and verified higher values of arylsulfatase enzyme activity in fallow soil. This result may be related to the deposition of different plant fractions in the soil, due to the plants diversity of the fallow area, which increases organic matter and soil microbial activity (HUNGRIA et al., 2009).

Among the soil microorganisms, only fungi have sulfate esters, which are substrates for arylsulfatase activity (BANDICK \& DICK, 1999). Its activity is related to the dense root system and continuous renewal of these fungi species (SPERA et al., 2004), which may have contributed to arylsulfatase enzyme activity.

Greater $\beta$-glucosidase enzyme activity in the soil was observed in the area planted with millet cover crop (299.50 $\mu \mathrm{g}$ p-nitrophenol $\mathrm{g} \mathrm{soil}^{-1} \mathrm{~h}^{-1}$ ) (Table 1), followed by U. brizatha, U. ruziziensis, crambe, and fallow. Sorghum, forage turnip, and stylosanthes presented the lowest values. $\beta$-glucosidase is related to the release of low molecular weight sugars from the decomposition of organic matter in the soil, being important sources of metabolic energy for soil microbiota (BANDICK \& DICK, 1999). Thus, soil management with the addition of vegetable residues and the maintenance of this cover crop in the soil, especially under no-tillage system, is a strategy to increase $\beta$-glucosidase activity (LISBOA et al., 2012). 
The highest soil basal respiration rates were observed in the treatments with millet, stylossanthes, and crambe cover crops, with $171.79 ; 162.67$ and $159.47{\mathrm{mg} \mathrm{C}-\mathrm{CO}_{2}} 100 \mathrm{~g} \mathrm{dry} \mathrm{soil}^{-1}$, respectively, being similar to each other (Figure 1). This evaluation refers to the degradation capacity of the organic matter by the heterotrophic microbiota, making possible the action in the carbon cycle (ARAÚJO \& MONTEIRO, 2007). Higher respiration rates may indicate some kind of disturbance in the system (ALVES et al., 2011), which occurred in this study, since the treatments with stylosanthes and crambe cover crops were also those that presented the lowest values of the enzymes acid phosphatase, $\beta$ glucosidase, and arylsulfatase in the soil (Table 1). Several factors influence soil respiration, such as the presence of microbial growth inhibitory substances, the chemical composition of the substrate, and soil nutrient factors (MERCANTE et al., 2008).

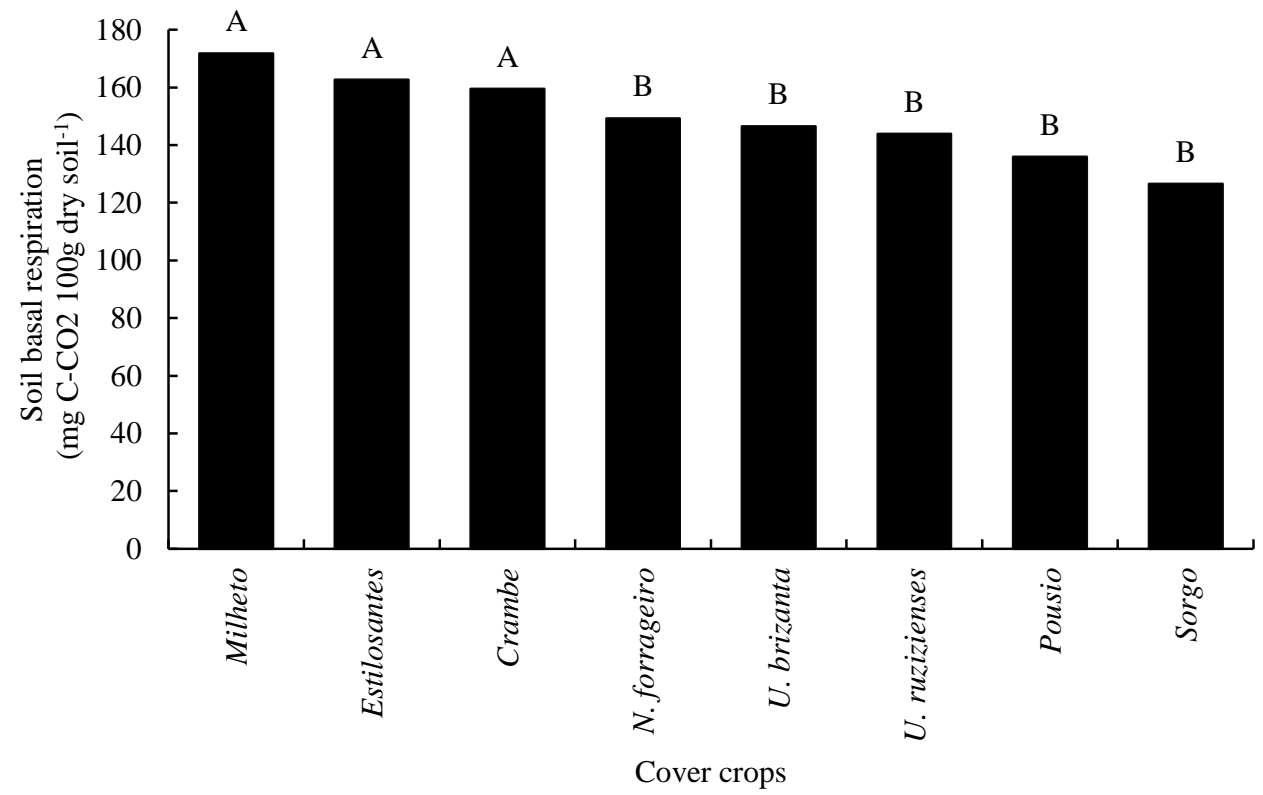

Figure 1. Basal respiration of soil cultivated with maize in succession to different cover crops grown in the winter crop. Chapadão do Sul, January/2016.

Conversely, the soil cultivated with millet cover crop, which presented respiration value similar to those observed for stylosanthes and crambe cover crops, stood out for the $\beta$-glucosidase enzyme activity. Thus, it can be inferred that basal respiration is related to the rapid decomposition of the straw, since the activity of this enzyme is an indicative of the occurrence of this process in the soil, as previously reported. Moreover, high soil basal respiration indicates high productivity level of the ecosystem 
(ISLAM \& WEIL, 2000), being a desirable characteristic when considering that the decomposition of organic residues will provide nutrients to the plant (ALVES et al., 2011).

Knowing the soil microbial activity in the different agricultural management systems is fundamental, as it supports the choice of the best use of the soil, aiming at soil quality and at a sustainable system. The cultivation of cover crops, as those used in this study, may change the quality of the residues deposited in the soil, modifying the community and its dynamics over time, consequently changing the Carbon and nutrients cycling (CORDEIRO et al., 2012).

\section{CONCLUSIONS}

The different cover crops used in succession to maize influenced soil quality biochemical indicators.

$U$. ruziziensis cover crop provided the best results in the attributes evaluated in the soil and climate conditions of the Cerrado region of the state of Mato Grosso do Sul.

\section{REFERENCES}

ALVES, T. DOS S.; CAMPOS, A.L.L.; NETO, N.E.; MATSUOKA, M.; LOUREIRO, M. F. 2011. Biomassa e atividade microbiana de solo sob vegetação nativa e diferentes sistemas de manejos. Acta Scientiarum. Agronomy, Maringá, v.33, n.2, p.341-347.

ARAÚJO, A.S.F.E; MONTEIRO, R.T.R. 2007. Indicadores biológicos de qualidade do solo. Bioscience Journal, Uberlândia, v.23, n.3, p.66-75.

BANDICK, A.K.; DICK, R.P. 1999. Field management effects on soil enzyme activities. Soil Biology Biochemistry, Amsterdam, 31:1471-1479.

CARNEIRO, M.A.C.; ASSIS, P.C.R.; MELO, L.B. DE C.; PEREIRA, H.S.; PAULINO, H.B.; NETO A.N. DA S. 2008. Atributos bioquímicos em dois solos de cerrado sob diferentes sistemas de manejo e uso. Pesquisa Agropecuária Tropical, Brasília, v.38, n.4, p.276-283.

CARVALHO, A.M. DE; COSER, T.R.; REIN, T.A.; DANTAS, R. DE A.; SILVA, R.R.; SOUZA, K.W. 2015. Manejo de plantas de cobertura na floração e na maturação fisiológica e seu efeito na produtividade do milho. Pesquisa agropecuária brasileira, Brasília, v.50, n.7, p.551-561.

CARVALHO, M.A.C. DE; ATHAYDE, M.L.F.; SORATTO, R.P.; ALVES, M.C.; ARF, O. 2004. Soja em sucessão a adubos verdes no sistema de plantio direto e convencional em solo de Cerrado. Pesquisa agropecuária brasileira, Brasília, v.39, n.11, p.1141-1148.

CHRISTOFFOLETI, P. J.; PASSINI, T. 1999. Manejo integrado de plantas daninhas na cultura do feijão. In: FANCELLI, A. L.; DOURADO NETO, D. Feijão irrigado: estratégias básicas de manejo. Piracicaba: LPV/ESALQ/USP, p.80-97.

CORDEIRO, M. A. S.; CORA, J. E.; NAHAS, E. 2012. Atributos bioquímicos e químicos do solo rizosférico e não rizosférico de culturas em rotação no sistema de semeadura direta. Revista Brasileira de Ciência do Solo [online], v.36, n.6, p.1794-1803. 
CUNHA, F.F.; MAGALHÃES, F.F.; CASTRO, M.A. 2013. Métodos para estimativa da evapotranspiração de referência para Chapadão do Sul - MS. Revista Engenharia na agricultura, Viçosa, v.21, n.2, p.159-172.

FERREIRA, D.F. 2011. Sisvar: a computer statistical analysis system. Revista Ciência Agrotecnologia, Lavras, v.35, n.6, p.1039-1042.

GALBIATTI, J.A.; SILVA, F.G.; FRANCO, C.F.; CARAMELO, A.D. 2011. Desenvolvimento do feijoeiro sob o uso de biofertilizante e adubação mineral. Engenharia Agrícola, Jaboticabal, v.31, n.1, p.167-177.

HEINZ, R.; GARBIATE, M. V.; NETO, A. L.V.; MOTA, L. H. DE S.; CORREIA, A. M. P.; VITORINO, A. C. T. 2011. Decomposição e liberação de nutrientes de resíduos culturais de crambe e nabo forrageiro. Ciência Rural, Santa Maria, v.41, n.9, p.1549-1555.

HUNGRIA, M.; FRANCHINI, J.C.; BRANDÃO-JUNIOR, O.; KASCHUK, G.; SOUZA, R.A. 2009. Soil microbial activity and crop sustainability in a long-term experiment with three soiltillage and two crop-rotation systems. Applied Soil Ecology, Amsterdam, v.42, n.3, p.288-296.

ISLAM, K. R.; WEIL, R. R. 2000. Land use effects on soil quality in a tropical forest ecosystem of Bangladesh. Agriculture Ecosystems and Environment, Rio de Janeiro, v.79, n.1, p.9-16.

LAGOMARSINO, A.; MOSCATELLI, M.C.; DI TIZIO, A.; MANCINELLI, S.; GREGO, S.; MARINARI, S. 2009. Soil biochemical indicators as a tool to assess the short-term impact of agricultural management on changes in organic $\mathrm{C}$ in a Mediterranean environment. Ecological Indicators, Amsterdam, v.9, p.518-527.

LAMBAIS, M.R.; CARMO, J.B. DO. 2008. Impactos da aplicação de biossólidos na microbiota de solos tropicais. Revista Brasileira de Ciência do Solo, Viçosa, v.32, p.1129-1138.

LEAL, A. J. F.; LAZARINI, E.; TARSITANO, M. A. A.; DE SÁ, M. E.; GOMES JÚNIOR, F. G. 2005. Viabilidade econômica da rotação de culturas e adubos verdes antecedendo o cultivo do milho em sistema de plantio direto em solo de cerrado. Revista Brasileira de Milho e Sorgo, Brasília, v.4, n.3, p.298-307.

LISBOA, B.B.; VARGAS, L.K.; SILVEIRA, A.O.D.; MARTINS, A.F.; SELBACH, P.A. 2012. Indicadores microbianos de qualidade do solo em diferentes sistemas de manejo. Revista Brasileira Ciência Solo, Viçosa, v.36, n.1, p.33-44.

MACHADO, L.A.Z.; ASSIS, P.G.G. DE. 2010. Produção de palha e forragem por espécies anuais e perenes em sucessão à soja. Pesquisa agropecuária brasileira, Brasília, v.45, n.4, p.415-422.

MERCANTE, F. M.; SILVA, R. F.; FRANCELINO, C. S. F.; CAVALHEIRO, J. C. T.; OTSUBO, A. A. 2008. Biomassa microbiana, em um Argissolo Vermelho, em diferentes coberturas vegetais, em área cultivada com mandioca. Acta Scientiarum Agronomy, Maringá, v.34, n.4, p.479-485.

NAHAS, E. 2002. Microorganismos do solo produtores de fosfatases em diferentes sistemas agrícolas. Bragantia, Campinas, v.61, n.3, p.267-275.

OERLEMANS, K.; BARRET, D.M.; SUADES, C.B.; VERKERK, R.; DEKKER M. 2006. Thermal degradation of glucosinolates in red cabbage. Food Chemistry, California, v. 95, p. 19-29.

PACHECO, L. P.; BARBOSA J. M.; LEANDRO, W. M.; MACHADO, P. L. O. A.; ASSIS, R. L.; BEÁTA EMOKE MADARI, B. E.; PETTER, F. A. 2011. Produção e ciclagem de nutrientes por plantas de cobertura nas culturas de arroz de terras altas e de soja. Revista Brasileira de Ciência do Solo, Viçosa, n.35, p.1787-1799.

REIS, E.M.; CASA, R.T.; BIANCHIN, V. 2011. Controle de doenças de plantas pela rotação de culturas. Summa phytopathol, Botucatu, v.37, n.3, p.85-91.

ROSOLEM, C A.; MERLIN, A.; BULL, J.C.L. 2014. Soil phosphorus dynamics as affected by Congo grass and P fertilizer. Scientia Agricola, Piracicaba, v.71, n.4, p.309-315, 
SPERA, S.T.; SANTOS, H.P. DOS; FONTANELI, R.S.; TOMM, G.O. 2007. Integração lavoura e pecuária e os atributos físicos de solo manejado sob sistema plantio direto. Revista Brasileira Ciência Solo, Viçosa, v.33, n.1, p.129-136.

TABATABAI, M. A. 1994. Soil enzymes. In: Methods of Soil Analysis, Part 2, Chemical and Microbiological Properties. Page AL, Miller EM, Keeney DR (eds). American Society of Agronomy, Madison, v.l, p.903-947.

Received in October 18, 2016

Accepted in August 7, 2017 